\title{
An Empirical Study of Customer Satisfaction towards Bank Payment Card Service Quality in Ho Chi Minh Banking Branches
}

\author{
Chia Nan Wang ${ }^{1}$, Nhu Ty Nguyen ${ }^{1,2} \&$ Thanh Tuyen Tran ${ }^{1,2}$ \\ ${ }^{1}$ Department of Industrial Engineering and Management, National Kaohsiung University of Applied Sciences, \\ Taiwan \\ ${ }^{2}$ International Relations Office, Lac Hong University, Bien Hoa city, Dong Nai, Vietnam \\ Correspondence: Nhu Ty Nguyen, International Relations Office, Lac Hong University, Bien Hoa city, Dong Nai, \\ Vietnam. Tel: 84-613-953-128. E-mail: nhutynguyen@gmail.com
}

Received: December 10, 2013

Accepted: February 27, 2014

Online Published: April 25, 2014

doi:10.5539/ijef.v6n5p170

URL: http://dx.doi.org/10.5539/ijef.v6n5p170

\begin{abstract}
Automated Teller Machines (ATMs) is very important for improving the banking service quality that can increase customer satisfaction by helping them to enjoy safe and convenient access. The investigation in this study is implemented by surveying the level of satisfaction among customers who are doing transactions at Vietnamese banking branches. Based on the model of service quality with the selected five key factors of tangible, reliability, responsiveness, communication, and security, the author aims at exploring significant dimensions that have much impact on customers' satisfaction with banking services.

The data are analyzed by using multiple statistical analyses including the analysis of exploratory factor, reliability, correlations, and multiple linear regressions. The results indicate that customer satisfaction has a positive impact on tangible and reliability factor, whereas responsiveness is the main cause of customer dissatisfaction. These findings make significant contributions to improve the service quality of bank payment cards in Ho Chi Minh city, Vietnam and to increasing competitiveness of the branches in the field of card self-services.
\end{abstract}

Keywords: automated teller machines, service quality, banking, customer satisfaction

\section{Introduction}

In Vietnam, as more and more businesses are getting global and the world economy is consistently changing, trade activities can cross the borders within minutes or short time. Not surprisingly, the bank's service in the payment system has caught the much attention, where customers are always concerned with the correctness, the safety, and the quickness with effectiveness. Thus, with the continuous development of foreign and domestic business, the activities of the demand for cash payment and/or deposit and money transfer are also getting frequent. For instance, the credit card has been increasingly popular in Vietnam as other developed countries.

Besides the traditional and credit card services, the commercial banks of Vietnam are constantly expanding a variety of services such as varied mortgage services, Internet services, the services between government and citizens, etc., where the banks try their best to grab at new or potential opportunities for their most benefits.

Since the early 90's, the Bank for Foreign Trade of Vietnam also planned to make a huge change in enhancing the banking services such as banking networking and the credit card application. Although the change implementation reaped significant harvest, some barriers such as the technological issues have been encountered and the difficulties such as people's habits and cheating events still exist in developing banking services. As such, many bank services mushroomed, including Bank of Agriculture and Rural Development, and tried to formulate competitive strategies with a view to dominate the banking market with better services, particularly in the card services.

Therefore, embracing competitive strategies of quality card services to satisfy customers' demand has played a very important role in banking services. After realizing the reality and importance of card services for the banking business, the understanding of customers' satisfaction can be obtained through surveying a specific case of banking branches in Ho Chi Minh city, Vietnam. In turn, it can also contribute to help building the competitive strategies for the banks in the field of card services. 
Automated teller machines (ATMs) came into being in 1968 and ever since then have been widely utilized. Since then, almost all banks take the advantages of using ATMs as a tool to serve the customers' needs. Upon seeing this trend, although it was quite late, banks in Vietnam started to issue the cards with comprehensive functionalities and utilities from the year 2007. The following objectives of the current study are:

Contingency analysis of business operations of the bank payment cards since the start-up of running business from year 2007 to the first half of year 2012.

In-depth analysis of customers' satisfaction with banking card services at Ho Chi Minh branches.

Provide alternatives to improving the service quality of bank payment cards.

\section{Literature Review}

The basic literature supports the notion that customer loyalty involves customer satisfaction, customer characteristic, dimensions of service quality and technology-based self-services in banking as the main elements of customer loyalty.

\subsection{Customer Satisfaction}

There have been many other definitions of customer satisfaction based on different aspects; such as, Kotler and Keller (2009) directly defined "satisfaction can also be a person's feelings of pleasure or disappointment that results from comparing a product's perceived performance or outcome with their expectations" or Sureshchander et al. (2002) expressed that "consumer's level of satisfaction is determined by his or her cumulative experience at the point of contact with the supplier". These two definitions examined the concept of customer satisfaction under the gap between pre-purchase and post-purchase or the gap between previous performance and current one.

\subsection{Customer Characteristics}

With the trend towards, the impact on service quality evaluation is done by survey and this would give out a chance to study more about providing services based on customer characteristics and technologies.

The customer characteristics, including self-motivation and experience, should play a very important role, if they are to do the services by themselves. There are five categories, Dabholkar (1996), Rogers (1995), and Parasuraman et al. (1991), to distinguish the customer characteristics and their determinants.

(1) Demographics (age, education, social integration);

(2) Personality (impatience, social risk, self-esteem);

(3) Behavior (self-motivation, consumption rate, technological experience);

(4) Relationship (organizational commitment);

(5) General attitudes (need for independence, need for social interaction and attitude towards using technology).

\subsection{Definition of Service Quality}

Service quality was also defined as "any behavior or act based on a contact between two parties: the provider and the receiver" by Kotler and Keller (2009). Quality is one of the things that consumers look for in an offer, which service happens to be one (Negi, 2010). Service quality in the management and marketing literature is the extent to which customers' perceptions of service meet or exceed their expectations for example as defined by Bowen and David (2005). Thus, service quality can intend to be the way in which customers are served in an organization which could be good or poor. Moreover, in the study of Wang, Nguyen and Tran (2014), they have defined some factors that have the strongest impact on the overall satisfaction of staff so that employees can improve much the serving to reach a certain level of service quality delivered to customers.

\subsection{Dimensions of Service Quality}

Ten determinants can have influence on service quality gap were described by Harvey (1988). They are competence; courtesy; credibility; security; access; communication; understanding; reliability; responsiveness.

\subsection{Definition of Banking Service Quality}

In banking field, Mohamed and Shirley (2009) emphasized that banks have to notice about the quality of their services because service quality is considered the core of strategic competition. As the research is focused on examining the level of service quality as perceived by customers and its effect customer satisfaction, the banking service quality is defined as "the overall excellence of bank service that satisfies user expectation". 


\subsection{Technology-Based Self-Services in Banking}

Teachnology-Based Self-Service in Banking are technological interfaces that enable customers to get a service independent of direct services without employee involvement (Meuter et al., 2000), through person-to-technology service delivery (Dabholkar, 1994). It is necessary for banks and other financial-related intermediaries to have information processing self-service technologies (Sannes, 2001). Self-services banking is the use of self-service technologies in banking. Examples of self-services banking include banking by telephone and the Internet, ATM, interactive kiosks and other self-service terminals.

As Sannes (2001) stated, the literature deemed three main areas important in conceptualizing a framework of self-services banking, they are the strategy about firm level value creation combined with bank specific issues, self-services banking information exchange and its implications on the customer relationship and STT added to a principal understanding of technology-based service encounters in a customer viewpoint. The following figure is Self-Services Technology-SST Model.

\subsection{Service Quality Model or GAP Model}

A customer's expectation of a particular service and their service perceived sometimes is not equal. Therefore, it leaves a gap. Harvey (1988) identified seven major 'gaps' that cause unsuccessful delivery:

(1) Gap between customers' expectations and management perceptions.

(2) Gap between management perceptions and service specifications.

(3) Gap between services specifications and services delivery. This gap is a result of owing to the services personnel, such as poor training or lack of teamwork.

(4) Gap between service delivery and external communication.

(5) Gap between the discrepancy and customer expectations and their perceptions of the service delivered.

(6) The discrepancy gap between customer expectations and employees' perceptions;

(7) The discrepancy gap between employee's perceptions and management perceptions.

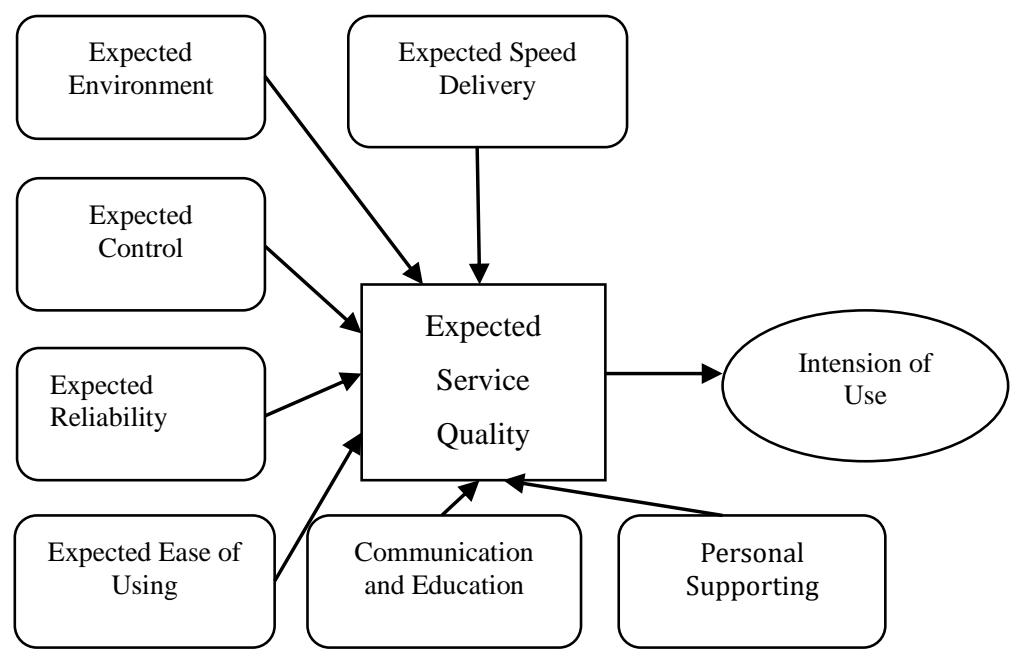

Figure 1. SST Attitude/ Intention to Use/Overall effect model

Dabholkar (1996) found out that the speed, enjoyment, controlling, reliability, communication, the ease to use of technology, and personnel supporting are those kinds of important attributes in measuring and utilizing the Technology-Based Self-Service towards customers.

(1) Speed to Deliver Services: Based on the speed of delivery, customers can easily choose and evaluate the technology-based self-service options, which were initially suggested by Dabholkar (1996).

(2) Enjoyable Services: Foley et al. (1990) indicated, the pleasure is a very important factor in determining how users evaluated quality of computer technology.

(3) Controlling process: As Langeard et al. (1981) stressed, using self-service technologies that customers may feel with the extent of control is one of the most important satisfaction factors. However, Bateson (1985) 
indicated that control is rather a complex concept matter like behavior, or decision making in personal service.

(4) Reliability: Reliability is the fact that a scale should consistently reflect the construct it is measuring. Ram (1989, p. 24) recommended four types of risks making customers more resistant to innovations in general: Functional risk; Economic risk; Social risk; Psychological risk.

(5) Easy to Use: Kelley et al. (1990), easy to use is a factor that help and satisfy customers, where they are willing to manage with clear mind and little effort. In a computer environment, Foley et al. (1990) also suggested three distinctive kinds of ways for easy-to-use services by being cognitive, perceptive and motoring to achieve the ergonomic qualities.

(6) Communication/Education: Currently, many banking institutes provide 24 hours self-services points such as ATMs and the persons on duty for exceptional handling with customers' requirements. Therefore, not only the staffs need specific trainings but also customers or clients have to be trained or self-trained in one way or another such as the basic application of computer and related networking.

- Personnel Supporting: For a bank providing 24 hours a day all the year, day time service is no doubt convenient and easy handling whether it is dealt with on the counter or self-service points such as ATMs and Internet access.

\section{Methodology}

\subsection{Research Hypotheses}

Among general instruments, the most popular model used for evaluation of service quality is SERVQUAL, a well-known scale developed by Parasuraman et al. (1988). The author selected five dimensions of Parasuraman's study and summarized them as below:

Security: The service offer free from risks and hazards defects or doubts. How company can provide bodily safety, financial security as well as privacy.

Communication: Company can offer easy understood communication, such as language, clear explanation.

Tangibles: The physical evidence of the service is consisted of physical facilities, tools and equipment and so on.

Reliability: The ability to perform the service as promise in a dependable and accurate manner.

Responsiveness: the willingness of service providers to help clients and satisfy their needs, immediately replies to their inquiries, and solve their problems as quickly as possible.

To provide focus and direction, research hypotheses of the current dissertation were formulated. They are as follows:

H1: Communication has a positive effect on customer satisfaction.

H2: Security has a positive effect on customer satisfaction.

H3: Tangible has a positive effect on customer satisfaction.

H4: Reliability has a positive effect on customer satisfaction.

H5: Responsiveness has a positive effect on customer satisfaction.

Data were primarily collected through questionnaires at bank branches among the area of Ho Chi Minh City. Two hundred questionnaires were sent to customers who did transaction at the bank or ATMs through email, letter and directly.

\subsection{Measurement Instrument}

The title of the research's questionnaire is "Customer satisfaction of ATM services in Ho Chi Minh city". The questionnaire used in this survey is composed of four parts: (1) demographic information questions; (2) 10 questions of using banking ATMs service; (3) 26 questions of satisfaction towards: reliability, tangible, communication, responsiveness and security and (4) 01 question of overall satisfaction level.

\subsection{Data Collection}

There were totally 500 questionnaires delivered; however, there were only 415 pieces collected with only 400 valid observations, which represented a response rate of $80 \%$. Modes of data collection in our survey are (1) telephone; (2) Mail (post); (3) Online surveys; (4) Personal in-office surveys; (5) Hybrids of the above.

\subsection{Method of Data Analysis}

Questionnaire Validity: Validity refers to whether the questionnaire or survey measures what it intends to measure. The overriding principle of validity is that it focuses on how a questionnaire or assessment process is 
used. Content validity referred to whether the instrument can cover items that purpose to cover. Mills and Morris (1986) recommends that literature had to be reviewed to get the theoretical knowledge about the content or definitions of concepts that are used before designing the instrument for the particular study.

\subsection{Questionnaire Reliability}

Reliability indicates degrees of consistency between multiple measurements of a variable. The lower limit for Cronbach's alpha is .70, although it may decrease to .60 in exploratory research. The present study adopts Fabrigar's (1999) suggestions with the value 0.6 deemed the lower limit of acceptability. And, to measure item reliability, we regard on the item-to-total correlation (the correlation of the item to the summated scale score). It is suggested that the item-to-total correlations should exceed 0.3.

Exploratory factor analysis (EFA) is a technique within factor analysis whose overarching goal is to identify the underlying relationships between measured variables. In multivariate statistics, EFA is a statistical method used to uncover the underlying structure of a relatively large set of variables.

Multiple regression analysis helps us to predict the value of $\mathrm{Y}$ for given values of $(\mathrm{X} 1, \mathrm{X} 2, \ldots, \mathrm{Xk})$

The objective of multiple regression analysis is to use the independent variables whose values are known to predict the single dependent value selected by the researcher. By multiple regressions, we mean models with just one dependent and two or more independent (exploratory) variables. The variable whose value is to be predicted is known as the dependent variable and the ones whose known values are used for prediction are known independent (exploratory) variables.

In general, the multiple regression equation of $\mathrm{Y}$ on $\mathrm{X} 1, \mathrm{X} 2, \ldots, \mathrm{Xk}$ given by:

$$
Y=b 0+b 1 X 1+b 2 X 2+\ldots+b k X k
$$

Here $b 0$ is the intercept and $b 1, b 2, b 3, \ldots, b k$ are analogous to the slope in linear regression equation and are also called regression coefficients. They can be interpreted the same way as slope. Thus if $b i=2.5$, it would indicates that $\mathrm{Y}$ will increase by 2.5 units if $\mathrm{Xi}$ increased by 1 unit.

Besides, the standardized regression coefficients $(\beta)$ reflect the relative impact on dependent variable of a change in one standard deviation in either variable. Now that we have a unit of measurement, we can determine which variable has the most impact.

R2-coefficient of determination: Once a multiple regression equation has been constructed, one can check how good it is (in terms of predictive ability) by examining the coefficient of determination (R2). R2 always lies between 0 and 1 . The closer R2 is to 1 , the better is the model and its prediction.

Correlation Analysis: The correlation coefficient, denoted by $r$, is a measure of the strength of the linear relationship between two variables. The correlation coefficient takes on values ranging between +1 and -1 . If correlation coefficient equal to 0 indicates no linear relationship, +1 indicates a perfect positive linear relationship: as one variable increases in its values, -1 indicates a perfect negative linear relationship: as one variable increases in its values. In details, if correlation coefficient values between 0 and $0.3(0$ and -0.3$)$ indicate a weak positive (negative) linear relationship via a shaky linear rule, between 0.3 and $0.7(0.3$ and -0.7$)$ indicate a moderate positive (negative) linear relationship via a fuzzy-firm linear rule, between 0.7 and 1.0 (-0.7 and -1.0) indicate a strong positive (negative) linear relationship via a firm linear rule.

\section{Data Analysis and Results}

\subsection{Determinants Impact on Customer by EFA}

Firstly, by the questionnaires, the study may introduce a survey to understand the perceptions of customers-a distinct and important demographic group-on how they intend to interact with their banks. In Table 1, we present Statistics of Customers' Characteristic who are using ATM services and details of follows:

Table 1. Statistics of customers' characteristic who are using ATM services

\begin{tabular}{llcc}
\hline Questions & Contents & Frequency & Percentage \% \\
\hline How do you get to know ATM & Doing transaction here & 180 & 45 \\
Services? & Heard from friends, relatives. & 176 & 44 \\
& Internet, newspaper. & 196 & 49 \\
& Television, radio. & 206 & 51.5 \\
& Panel & 180 & 45 \\
\hline
\end{tabular}




\begin{tabular}{llcc}
\hline & Any other-please specify & 146 & 36.5 \\
What are the positive features of & Safety and security & 218 & 54.5 \\
ATM services? & The cards are easy to keep and use & 398 & 99.5 \\
& The cards are well- decorated & 306 & 76.5 \\
& Time savings, 24/365 & 358 & 89.5 \\
& Satisfied with service quality & 110 & 27.5 \\
& Any other-please specify & 58 & 14.5 \\
What are the uncomfortable & Poor money quality & 94 & 23.5 \\
features/issues of ATM services? & Delay in card delivering & 100 & 25.0 \\
& Machine problems & 148 & 37.0 \\
& Card locking & 136 & 34.0 \\
& Unsecured & 266 & 66.5 \\
& Unsuitable location & 250 & 62.5 \\
What are your recommendations & Better customer service & 316 & 79 \\
to improve ATM service quality? & Good technological machine & 112 & 28 \\
& Prompt card delivery & 126 & 31.5 \\
& New convenient locations for ATM & 316 & 79 \\
& More withdrawal limit & 100 & 25.0 \\
& Any other-please specify & 88 & 22 \\
\hline
\end{tabular}

Before doing factor analysis, we used Kaiser-Meyer-Olkin Measure of Sampling Adequacy (KMO) and Bartlett Test of Sphericity to verify if the 26 items of the questionnaire is suitable for factor analysis. As shown in Table 2 the KMO is higher than 0.7 and the significance is lower than 0.01 . Then we concluded that the 26 -subject questionnaire is suitable for factor analysis.

Table 2. KMO and Bartlett's test

\begin{tabular}{lll}
\hline Kaiser-Meyer-Olkin Measure of Sampling Adequacy. & 0.765 \\
\hline Bartlett's Test of Sphericity & Approx. Chi-Square & $2.393 \mathrm{E} 3$ \\
& $\mathrm{df}$ & 235 \\
& Sig. & .000 \\
\hline
\end{tabular}

Factor analysis was also carried out on 3 items (A6, A9, A26) with relatively low factor loadings $(<0.5)$ and difference of factor loading within 0.1 were eliminated, thus 23 remained. After performing factor analysis, 23 items was finally summarized to 7 underlying factors and they explain 70,179 percent of variance.

As Table 3 shows, 7 underlying factors were summarized as the 6-dimension. Firstly, the 6-item X1, X2, X3, X4, X5, and X10 is Tangible. Secondly, the 2-item X7 and X8 is Reliability. Thirdly, the 3-item X11, X12, X13, X14, $\mathrm{X} 15$ and X16 is Responsiveness. Similarly, these items X17, X18, X19, X20, and X21 were gathered in the factor four and named as Communication. The group X22, X23, X24, and X25 was named as Security.

Table 3. Rotated component matrix for the final step

\begin{tabular}{lc}
\hline \multicolumn{1}{c}{ Statements } & Components and factor loadings \\
\hline Tangible & \\
X1 Good decoration and tidiness & .823 \\
X2 Made by materials that are friendly with the environment & .784 \\
X4 ATM locations are suitable & .752 \\
X3 The quality of notes are good & .746 \\
X6 ATM has modern and easy to use I-technique & .584 \\
X5 Cameras, video recorder, alarm, light are in good conditions & .583 \\
Reliability & \\
X7 Time savings, 24h/24h & .829 \\
X8 Query response, timely action on request are easy to understand & .802 \\
Responsiveness & \\
X12 Express prompt card delivery and services & .822 \\
\hline
\end{tabular}




\begin{tabular}{ll}
\hline X13 Personnel tries to understand customer's problems & .773 \\
X11 Good cooperation with call center & .630 \\
X15 Customers don't wait for long time to talk to customer services & .822 \\
X14 Personnel makes effort to resolve customers' problems & .773 \\
X16 Providing prompt answers to customers' questions & .630 \\
Security & \\
X24 Creativity and innovation are always supported & .778 \\
X22 Handling to re-issue card when lost or broken & .757 \\
X23 Resolve customers' problem well & .630 \\
X25 Boots have secure, comfortable and private space & .599 \\
Communication & \\
X19 Giving customers individual attention & .839 \\
X18 Recognizing regular customers in later call & .792 \\
X17 Answering the call with soft voice & .754 \\
X21 Knowledgeable and friendly communication & .848 \\
X20 Personnel are courteous and polite & .605 \\
\hline
\end{tabular}

\subsection{Correlation Analysis}

In this section, researcher used correlation analysis to measure the relationship between each factor and job satisfaction of customers who are using banking service in Ho Chi Minh city, Vietnam. A strong or high correlation means that two or more factors have a strong relationship with overall satisfaction while a weak or low correlation means that the factors are hardly related.

Correlation coefficients can range from -1.00 to +1.00 . The value of -1.00 represents a negative correlation while a value of +1.00 represents a perfect positive correlation. A value of 0.00 indicates that there is no relationship among the factors being tested (Fabrigar, 1999).

The bivariate correlation procedure is applied to analyze the relation between dependent variable overall satisfaction and two independent variables Assurance and Security. In the Table 4(a), correlation matrix supports all hypothesized positive relationship among these variables with high statistical significant. Tangible is found to be significantly and positive correlated with customer satisfaction (correlation coefficient or " $\mathrm{r} "=0.779$ ). Reliability is found to be significantly and positive correlated with customer satisfaction (correlation coefficient or " $\mathrm{r}$ " $=0.438$ ). Responsiveness is found to be significantly and negative correlated with customer satisfaction (correlation coefficient or " $\mathrm{r} "=-.174)$. Communication is found to be significantly and positive correlated with customer satisfaction (correlation coefficient or " $\mathrm{r}$ " $=0.338$ ). Security is found to be significantly and positive correlated with teacher satisfaction (correlation coefficient or " $r "=0.410$ ).

Generally speaking, we want to test whether explanatory variable had a positive (or negative) effect on explained variable using regression analysis. Correlation analysis is related in the sense that both deal with relationships among variables. The correlation coefficient is a measure of linear association between two variables. It does not seem reasonable that this study conclude Tangible, Reliability, Communication and Security have a positive effect on customer satisfaction and Responsiveness has a negative effect on customer satisfaction.

Table 4(a). Correlations analysis for five factor and satisfaction

\begin{tabular}{llll}
\hline Factor & Pearson Correlation & Sig.(2-tailed) & $\mathrm{N}$ \\
\hline Tangible & .779 & .000 & 400 \\
Reliability & .438 & .000 & 400 \\
Responsiveness & -.174 & .014 & 400 \\
Communication & .338 & .000 & 400 \\
Security & .410 & .000 & 400 \\
Overall Satisfaction & 1 & & 400 \\
\hline
\end{tabular}

\subsection{Multiple Linear Regressions}

The objective of multiple regression analysis is to predict the changes in the dependent variable in response to changes in the independent variables. This objective is most often achieved through the statistical rule of least squares. Whenever the researcher is interested in predicting the amount or magnitude of the dependent variable, 
multiple regressions is useful. For example, monthly expenditure on dining out (dependent variable) might be predicted from information regarding a family's income, its size, and the age of the head of household (independent variable).

The research's objective is to predict the changes of general customer satisfaction (dependent variable) in the relationship with Tangible, Reliability, Responsiveness, Communication and Security (independent variable). In detail, general satisfaction level will be predicted from information regarding inside factors: Tangible, Reliability, Responsiveness, Communication and Security.

In this section, by using multiple linear regressions the researcher selects one single dependent value, named as the overall customer satisfaction and five independent values, named as Tangible, Reliability, Responsiveness, Communication and Security to make a prediction.

Table 4(b). Model summary

\begin{tabular}{|c|c|c|c|c|c|c|c|c|c|}
\hline \multirow{2}{*}{ Model } & \multirow{2}{*}{$\mathrm{R}$} & \multirow{2}{*}{ R Square } & \multirow{2}{*}{ Adjusted R Square } & \multicolumn{6}{|c|}{ Std. Error of the Change Statistics } \\
\hline & & & & Estimate & R Square Change & F Change & df1 & df 2 & Sig. F Change \\
\hline 1 & $.797 \mathrm{a}$ & .636 & .630 & .502 & .636 & 113.976 & 3 & 196 & .000 \\
\hline
\end{tabular}

Predictors: (Constant), Tangible, Reliability, Responsiveness, Communication and Security.

Dependent Variable: Overall Customer Satisfaction.

SPSS will generate quite a few tables in its results section for a linear regression. In this session, we are going to look at the important tables. The first table of interest is the Model Summary table (Table 4(b)). This table provides the $\mathrm{R}$ and $\mathrm{R} 2$ value. The $\mathrm{R}$ value is 0.796 , which represents the simple correlation and, therefore, indicates a high degree of correlation. The $\mathrm{R} 2$ value indicates how much of the dependent variable, overall satisfaction of customers, can be explained by the independent variable, Tangible, Reliability, Responsiveness, Communication and Security. In this case, $63.6 \%$ can be explained, which is very large.

Note: In statistics, the coefficient of determination R2 is used in the context of statistical models whose main purpose is the prediction of future outcomes on the basis of other related information. $\mathrm{R} 2$ is most often seen as a number between 0 and 1.0, used to describe how well a regression line fits a set of data. An R2 near 1.0 indicates that a regression line fits the data well, while an $\mathrm{R} 2$ closer to 0 indicates a regression line does not fit the data very well. The coefficient of determination $(\mathrm{R} 2=0.63)$ shown in Table $4(\mathrm{~b})$ indicates that our regression line fits the data.

The next table is the ANOVA table. This table indicates that the regression model predicts the outcome variable significantly well. How do we know this? Look at the "Regression" row and go to the Sig. column. This indicates the statistical significance of the regression model that was applied. Here, $P<0.0005$ which is less than 0.05 and indicates that, overall, the model applied is significantly good enough in predicting the outcome variable (see Table 4(c)).

Table 4(c). ANOVA

\begin{tabular}{lllllll}
\hline Model & Sum of Squares & Df & Mean Square & F & Sig. \\
\hline 1 & Regression & 86.149 & 5 & 17.230 & 67.875 & $.000 \mathrm{a}$ \\
\multicolumn{1}{c}{ Residual } & 49.246 & 194 & .254 & & \\
\multicolumn{1}{l}{ Total } & 135.395 & 199 & & & \\
\hline
\end{tabular}

Predictors: (Constant), Security, Responsiveness, Reliability, Communication, Tangible.

The regression output, reproduced in Table 5 shows that Communication and Security factors are not significant $($ sig $>5 \%)$. These variables barely fail to reach significance. 
Table 5. Predictors_1 coefficients

\begin{tabular}{llllll}
\hline \multicolumn{1}{c}{ Model } & \multicolumn{2}{c}{ Un-standardized Coefficients } & Standardized Coefficients & t & Sig. \\
& $\mathrm{B}$ & Std. Error & Beta & 2.225 & .016 \\
\hline Constant & .680 & .305 & -- & 12.854 & .000 \\
Tangible & .163 & .013 & .711 & 3.233 & .001 \\
Reliability & .083 & .026 & .155 & -2.200 & .029 \\
Responsiveness & -.021 & .010 & -.097 & -.536 & .592 \\
Communication & -.010 & .018 & -.027 & .337 & .737 \\
Security & .006 & .017 & -.017 &
\end{tabular}

Those are one by one removed from the regression model and the final output is shown in table 6 .

(1) All the explanatory variables are statistically significant with the significant index $<0.05$.

(2) All has positive coefficients, which mean that tangible, reliability, and responsiveness have positive correlations with customer satisfaction.

(3) Standardized Coefficients of Tangible, Reliability, and Responsiveness are 0.707, 0.156, -.099 respectively. These indexes indicate that Tangible factor plays the most important role in making customers satisfied. Besides, Reliability occupied the second position and Responsiveness with Standardized Coefficients equals to negative value (-.099) is the factor that makes customers dissatisfied.

Table 6. Predictors_2 coefficients

\begin{tabular}{|c|c|c|c|c|c|}
\hline \multirow{2}{*}{ Model } & \multicolumn{2}{|c|}{ Un-standardized Coefficients } & \multirow{2}{*}{$\begin{array}{l}\text { Standardized Coefficients } \\
\text { Beta }\end{array}$} & \multirow{2}{*}{$\mathrm{t}$} & \multirow{2}{*}{ Sig. } \\
\hline & B & Std. Error & & & \\
\hline Constant & .696 & .287 & -- & 2.422 & .016 \\
\hline Tangible & .162 & .011 & .707 & 14.962 & .000 \\
\hline Reliability & .084 & .025 & .156 & 3.321 & .001 \\
\hline Responsiveness & -.021 & .009 & -.099 & -2.287 & .023 \\
\hline
\end{tabular}

Dependent Variable: General Satisfaction of Customers.

- What is the un-standardized regression equation?

Overall Satisfaction $=0.696+0.162$ Tangible +0.084 Reliability $(-0.021)$ Responsiveness .

- Which predictors are statistically significant? Tangible, Reliability, Responsiveness.

The table above, Coefficients, provides us with information on each predictor variable. This provides us with the information necessary to predict overall satisfaction of customers from Tangible, Reliability, and Responsiveness. We can see that both the constant and Tangible, Reliability, and Responsiveness contribute significantly to the model (by looking at the Sig. column). By looking at the B column under the Un-standardized Coefficients column we can present the regression equation as: Overall Satisfaction $=0.696+0.162$ Tangible +0.084 Reliability (-0.021) Responsiveness.

\section{Discussion and Solution}

In this study, the author examined satisfaction with customers using banking service through multilevel analyses of the survey conducted in Ho Chi Minh City, Vietnam. Thus, this study aims (1) to know the practical situation of how customers are using payment cards, (2) to examine which factors are determinants affecting the satisfaction of customers in terms of self-services banking system, and (3) to analyze individual-level variables as to the influence on level of satisfaction.

The findings show that while the factors of tangible benefits and reliability have significantly positive influence on customer satisfaction, the factor of responsiveness shows significant dissatisfaction. In addition, customer satisfaction varied with their income level and educational background. These factors can be discussed in depth and detail for managerial implications. Therefore, this study may give an insight into improving service quality in areas of reliability, responsiveness and tangibles for the enhancement of customer satisfaction. 


\subsection{Customized Services with Tangible Benefits}

Customized services are the services when you need any service personalized to your intent. In general, banks like other manufacturing companies would like to provide an interactive service customization model to support individual service offering for customers. In other words, companies with customized products and services offer products and services customized for their customers. The technology-based self-services are often a solution-based business customized to the private equity separate account needs for their clients. On top of that, bank networking make every attempt to employ mass customization, like in marketing, manufacturing, etc., coupled with the use of flexible computer-aided systems to produce custom output. This is because a tremendous increase in variety and customization does not cause a corresponding increase in costs.

For a firm, the tangible benefits may include the labour costs reduction, the equipment expense reduction, the space and overhead costs reduction, the inventory costs reduction, the bad debts reduction, or sales increase. These tangible benefits can be transferred to customers as customers' tangible benefits. For instance, customers can get the benefits if the expense of inter-bank money or transaction transfer is reduced or eliminated. Another example is that if the Internet is very secure, customers may make the transactions fast with convenience and free of charge.

In this study, customers expect to receive tangible improvements in the suitability of products and services customized to their needs. Thus, as to large retail banks, they should offer quality service delivery of personalization and flexibility customers want, and also lower costs through mass customization to generate more sustainable profits.

To achieve the goal of customized services with tangible benefits, it is very competitive for the retail bank by the use of innovative and cutting-edge technology to deliver quality service. It is exceptionally competitive since the smart phone started to be popular. However, this can help to maintain intimacy at a greater distance as customers move towards Internet, networking, or digital banking with greater self-services.

Customers prefer online channels with simple transactions, but they also demand high-quality, friendly or comfortable, and secure personal service, especially the more complex transactions with guidance. They require ambient environments of physical facilities, equipment, personnel, and communication materials. They may also be very interested in modern facilities and locations, for instance, ATM and locations. Thus, bank owners should examine ATM and banking services frequently to make improvements.

\subsection{Reliability-More Accuracy and Flexibility with Lowest Costs}

In present research, reliability is found as one of the most important factors from the banking services. Actually, since most customers are concerned about the reliability of virtual service providers, banking services providers should take more care about it. Employees in the front desk or internet banking continuously play an important and irreplaceable role behind banking service.

For physical banking, customers always focus on employees' performance. Therefore, bank owners has to pay more attention to staffs' working performance and give more chances of training and promotion for them in order to instill customers' confidence in banking services.

For Internet or other networking banking, customers use computers or make transaction at ATM. It is important for the bank to deal with business both online and offline. It's recommended that technical function and accurate record should be carefully noticed by the banking service providers.

Banks can also develop flexible loyalty program due to the fact that most customers are attracted by financial rewards. Although costly, such rewards offer huge potential benefits in loyalty and advocacy. Banks can embrace programs for affinity groups and let customers choose rewards attracting to them.

\subsection{Responsiveness: Friendly Attitudes and Prompt Services}

To have a better performance for a bank, the responsiveness is an important factor which necessitates friendly attitudes and prompt services shown in this survey. Thus, employees at front desk have to be friendly, and actively and positively responsive to customers' needs or questions. In so doing, if customers' expectation is met, their impression of the services may increase the satisfaction. In addition, prompt services are also essential that may streamline the services and then increase the level of customers' satisfaction.

Accordingly, bank owners should improve both physical banking service and internet banking service to give customers the best prompt services. Besides that, applying technology in banking service is a good way to enhance service responsiveness. Since the internet handles matters faster and easier in transaction for both customers and service providers, Internet banking has improved customers service better, especially for service 
responsiveness. The factor of responsiveness can be characterized by the following services using as an example.

(1) The promptness of card delivery and services.

(2) The understanding of customers' problems attempted by banking personnel.

(3) The best way to resolve customers' problem made banking personnel.

(4) The reduction of waiting time to satisfy customer needs.

(5) The promptness of answering customers' questions.

Therefore, it's very important for managers to take specific factors into close consideration, in that the service quality may affect customers' satisfaction performed by banks in Ho Chi Minh City, Vietnam. Managers must explore the most important factors in service quality and then deal with them properly. More importantly, the key five factors of tangible, reliability, responsiveness, assurance and empathy may have the combined effect on customer satisfaction. Hence, managers can manage well their resources to improve the overall perceived service quality in the banking sector.

\section{Contributions}

The researcher did the investigation of customer satisfaction in the case of banking services in Ho Chi Minh City, Vietnam. The results indicate that customer satisfaction and service quality can be hugely improved through self-services technology. In the current study, the five determinant factors in banking service quality are tangible, reliability, responsiveness, assurance and empathy.

\section{Limitations and Future Research}

This research was designed to test hypotheses of only five factors of service quality related to customer satisfaction. However, there are other variables that may have effect on customer satisfaction. Future research can test them for the generalization.

Another limitation lies in the fact that the data were collected in a single urban city in which the number of respondents is restricted. Thus, the sample size can be larger in the future research and banking services need to be across more Vietnamese and foreign banks.

\section{References}

Bateson, J. E. G. (1985). Self-service consumer: An exploratory study. Journal of Retailing, 61(3), 49-76.

Bowen, R., \& David, E. (2005). Service Quality (pp. 340-341). Blackwell Encyclopaedic Dictionary of Human Resource management.

Dabholkar, P. A. (1991). Using technology-based self-service options to improve perceived quality. In P. A. Dabholkar (Ed.), Enhancing knowledge development in marketing (pp. 534-535). Chicago, Illinois: American Marketing Association.

Dabholkar, P. A. (1994). Technology-based service delivery: A classification scheme for developing marketing strategies. Advances in Service Marketing and Management, 3, 241-271. http://dx.doi.org/10.1016/S1067-5671(94)03021-9

Dabholkar, P. A. (1996). Consumer evaluations of new technology-based self-service options: An investigation of alternative models of service quality. International Journal of Research in Marketing, 13(1), $29-51$. http://dx.doi.org/10.1016/0167-8116(95)00027-5

Fabrigar, L. R., Wegener, D. T., Mac, C., Robert C., \& Strachan, E. J. (1999). Evaluating the use of exploratory factor analysis in psychological research. Psychological Methods, 4(3), 272-299. http://dx.doi.org/10.1037/1082-989X.4.3.272

Foley, J., Van Dam, A., Feiner, S., \& Hughes, J. (1990). Computer graphics principles and practice (2nd ed.). Addison-Wesley.

Harvey, J. (1988). Service quality: A tutorial. Journal of Operations Management, 16, 583-597. http://dx.doi.org/10.1016/S0272-6963(97)00026-0

Kelley, S. W., Donnelly, J. H., \& Skinner, S. J. (1990). Customer participation in service production and delivery. Journal of Retailing, 66(3), 315-335.

Kotler, P., \& Keller, K. L. (2009). Marketing management (13th ed.). New Jersey: Pearson Education Inc, Upper Saddle River.

Langeard, E., John, B., Christopher, H. L., \& Pierre, E. (1981). Services marketing: New insights from 
consumers and managers. Report No. 81-104. Cambridge, MA: Marketing Science Institute.

Meuter, M. L., Ostrom, A. L., Roundtree, R. L., \& Bitner, M. J. (2000). Self-service technologies: Understanding customer satisfaction with technology-based encounters. Journal of Marketing, 64(3), 50-64. doi:http://dx.doi.org/10.1509/jmkg.64.3.50.18024

Mills, P. K., \& Morris, J. H. (1986). Clients as 'Partial' employees of service organizations: Role development in client participation. Academy of Management Review, 11(4), 726-735.

Mohamed, H., \& Shirley, L. (2009). Customer perception on service quality in retail banking in Middle East: The case of Qatar. International Journal of Islamic and Middle Eastern Finance and Management, 2(4), 338-350. http://dx.doi.org/10.1108/17538390911006386

Negi, R. (2010). Determining satisfaction through customer-perceived service quality and value: evidence from Ethiopian Telecommunications. International Journal of Services and Operations Management, 7(3), 333350. http://dx.doi.org/10.1504/IJSOM.2010.035056

Parasuraman, A., Berry, L. L., \& Zeithaml, V. A. (1991). Refinement and reassessment of the SERVQUAL Scale. Journal of Retailing, 67(4), 420-451.

Parasuraman, A., Zeithaml, V. A., \& Berry, L. L. (1988). SERVQUAL: A multiple-item scale for measuring consumer perceptions of service quality. Journal of Retailing, 64(1), 12-40.

Ram, S. (1989). The successful innovation of using strategies to reduce consumer resistance, an empirical test. Journal of Product Innovation Management, 6(1), 20-34. http://dx.doi.org/10.1016/0737-6782(89)90011-8

Rogers, E. M. (1995). Diffusion of innovations. New York, NY: Free press.

Sannes, R. (2001). En kartleggingavnorske bankers Internettkontor: En ekspertbedømmelse. An Evaluation of Nor-wegian Banks' Internet Services. Research Report, 18/2000.

Sannes, R. (2001). Self-service banking: Value creation models and information exchange. Informing Science, $4(3), 139-148$.

Sureshchandar, G. S., Rajendran, C., \& Anantharaman, R. N. (2002). The relationship between service quality and customer satisfaction-A Factor Specific Approach. Journal of Services Marketing, 16(4), 363-379. http://dx.doi.org/10.1108/08876040210433248

Wang, C. N., Nguyen, N. T., \& Tran, T. T. (2014). The study of staff satisfaction in consulting center system: A case study of job consulting centers in Ho Chi Minh City, Vietnam. Asian Economic and Financial Review, 4(4), 472-491.

\section{Copyrights}

Copyright for this article is retained by the author(s), with first publication rights granted to the journal.

This is an open-access article distributed under the terms and conditions of the Creative Commons Attribution license (http://creativecommons.org/licenses/by/3.0/). 